\title{
Překvapivé chyby v léčbě žilního onemocnění. Jak se jim vyhnout?
}

\author{
MUDr. Júlia Černohorská, Ph.D. \\ Dermal Centre Mělník
}

MUDr. Júlia Černohorská představila některé znepokojující výsledky českého průzkumu týkající se péče o pacienty s chronickým žilním onemocněním (CVD, chronic venous disease). Zdůraznila nízkou motivaci pacientů k dodržování režimových opatření a kompresivní léčby, ale také např. nedostatečné používání ultrasonografického vyšetření a cévních chirurgických zákroků u tohoto onemocnění, které má prokázaný progredující charakter a bez léčby často vede až rozvoji bércových vředů významně snižujících kvalitu života pacienta. Podtrhla důležitost tří základních pilírů léčby CVD - kompresivní léčby, podávání ověřených venofarmak a režimových opatření. U tohoto onemocnění aspekce vnějších známek ne vždy odpovídá závažnosti postižení a výskytu a tíži př́znaků. Proto na něj nelze spoléhat, je třeba odebrat pečlivě anamnézu, provést specializovaná vyšetření a včas zahájit léčbu zahrnující všechny 3 složky.

\section{Průzkum CVD Control v ČR}

MUDr. Černohorská je dermatoložka, která se věnuje převážně léčbě chronických ran a flebologii. Velkou část jejích pacientů tvoří jedinci s bércovými vředy žilní etiologie. V roce 2019 se zúčastnila 3měsičního průzkumu CVD Control, který mapoval péči o jedince s chronickým cévním onemocněním a který ukázal, že toto celoživotní progredující onemocnění je mnoha pacienty, ale i lékaři stále podceňované (1).

Průzkum CVD Control proběhl od března do června 2019 a zúčastnilo se ho 89 lékařu (62 \% dermatologů, 35 \% angiologů a 13 \% cévních chirurgů), kteř́ zařadili 890 pacientů, průměrného věku 61 let, ze 68 \% žen. Zařazeni byli ale i pacienti mladší 30 let.

\section{Opoždění diagnózy CVD}

Průzkum ukázal několikaleté zpoždění mezi rozvojem prvních přiznaků CVD a návštěvou lékaře z důvodu těchto př́iznaků. Procento pacientů se zpožděním diagnózy bylo vysoké zejména v mladších věkových skupinách. To je znepokojující výsledek vzhledem ke známému progredujícímu charakteru onemocnění. Výsledky studií naznačují, že přibližně u 1/3 až 1/2 pacientů s CVD dojde k progresi choroby během 10 let (2).

\section{Př́źznaky vs. projevy CVD}

Nejčastější projevy a př́iznaky, pro které byla léčba zahájena, byly obvyklé - pocit těžkých nohou, otok, bolest, kožní změny, pocit napětí, křeče a pocit otoku, Obr. 1. (1). Důležité ovšem je, že viditelné klinické projevy ne vždy odpovídají subjektivním obtízím pacienta (3). Retikulární žily a teleangiektázie mohou vyvolat př́znaky podobné těm, které se vyskytují u rozsáhlých křečových žil. Aby bylo dosaženo včasného zahájení léčby, je důležitá i řádná anamnéza. Pozornost je třeba věnovat rizikovým faktorům predikujícím možný vznik bércového vředu žilní etiologie. Patři mezi ně zejména kožní změny, prodělaná hluboká žilní trombóza, vyšší BMI, prítomnost refluxu, kouření a snižená hybnost kotníku $(3,4)$.

\section{Režimová opatření}

Nepř́iznivým faktem ovšem zůstává, že i když jsou pacienti informováni o rizicích, nejsou ochotni změnit svưj životní styl (5). Obtižně je dosahováno zejména doporučeného snížení tělesné hmotnosti a zvýšení pohybové aktivity. Snadnější je motivovat pacienty k tzv. žilní gymnastice. Cviky vestoje, vsedě či vleže si mohou pacienti osvojit např. na webových stránkách www.zilniporadna.cz nebo www.krecove-zily.cz. Žilní gymnastika zlepšuje činnost svalové pumpy, která je jedním z mechanismů zachování toku krve v žilách směrem k srdci.

\section{Ultrasonografické vyšetření}

Dalším nepříznivým zjištěním průzkumu bylo, že u 32 \% pacientů s CVD nebylo provedeno ultrasonografické vyšetření. Z těchto pacientů bez ultrasonografického vyšetření mělo dokonce $27 \%$ bércový vřed. Toto vyšetření pacientům upřeli predevším dermatologové (neindikovali jej u $40 \%$ pacientů, angiologové a cévní chirurgové pak u 19\%, resp. $18 \%$ pacientů) (1).

Obr. 1. Príznaky chronického žilního onemocnění, kterým je třeba věnovat pozornost pri diagnostice (1)

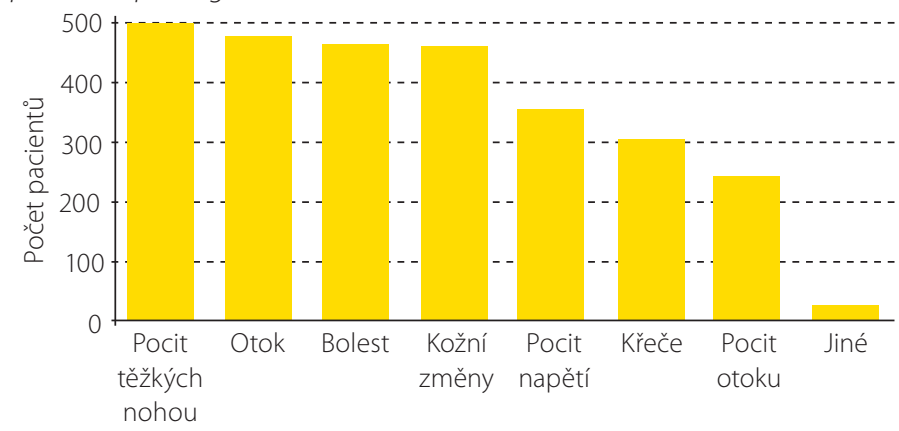




\section{Kompresivní terapie}

Přestože je kompresivní léčba jedním ze 3 základních pilírư léčby CVD a u pacientů, kteří zahájili nošení kompresních punčoch, nebo pokračovali v jejich nošení, byla zaznamenána menší progrese CVD než u pacientů bez komprese, ukázal český průzkum nedostatečné využíván této léčebné modality. Zcela bez komprese bylo 20 \% pacientů a $44 \%$ jich používalo kompresi nepravidelně (pouze při obtižích nebo sezónně) (1) Nabídka pomůcek pro kompresivní léčbu je dnes opravdu široká. Kromě bandáže a kompresivních punčoch Ize u aktivních osob využít kompresivní systém na suché zipy plně hrazený pojištovnou. Existuje i řada pomůcek, např. navlékače kompresivních punčoch, instruktážní videa na nakládání bandáže nebo např. speciální obuv pro pacienty s bandáží. O těchto možnostech by měl lékař pacienta informovat a zvýšit tak jeho compliance s touto neoblíbenou formou terapie.

\section{Intervenční léčba}

Chirurgický zákrok v léčbě CVD podstoupilo 32 \% pacientů z průzkumu. Větší podíl byl zjištěn u osob s méně závažnými stadii CVD (COs-C3) (1). Pacienty podstupující tento zákrok je ovšem třeba informovat o tom, že při unilaterálních varixech se do 5 let po zákroku v polovině prípadů rozvine CVD i ve druhé původně asymptomatické dolní končetině (5). Ke konzultaci k cévnímu chirurgovi by měl být odeslán každý pacient s žilním bércovým vředem. Podle osobních zkušeností Dr. Černohorské se při správně stanovené diagnóze a správném cévním výkonu zhojí bércový vřed obvykle do 8 týdnů.

\section{Venoaktivní léky}

Pokud se týká podávání venofarmak, uživalo je v průzkumu CVD Control 85 \% pacientů (1). Venofarmaka tvoři vedle komprese a režimových opatrení třetí základní piliř léčby CVD. Podávání venoaktivních léků je spojeno s dobrou compliance ze strany pacientů. Většina účastníků v průzkumu užívala mikronizovanou purifikovanou flavonoidní frakci (MPFF, Detralex ${ }^{\circledast}$ ). Jde o prípravek, který má v mezinárodních doporučeních pro léčbu CVD nejsilnější doporučení pro všechna stadia od C0s do C6 a jako jediné venofarmakum je indikován také u pacientů s bércovými vředy žilní etiologie (6). Svého komplexního mechanismu účinku dosahuje MPFF díky synergickému působení kombinace 5 flavonoidů - diosminu, hesperidinu, isorhoifolinu, linarinu a diosmetinu $(7,8,9)$. V experimentálních i klinických studiích MPFF prokázala, že zvyšuje žilní tonus, snižuje otok, zlepšuje trofiku kůže, podporuje hojení ran, zlepšuje kvalitu života a zmírňuje príznaky CVD (10)

\section{Etiopatogenetické mechanismy u CVD}

Důvodem, proč CVD vyžaduje komplexní terapii, je patofyziologie tohoto onemocnění spočívající v souboru souběžně probíhajících dějů. Predispozicí

Obr. 2. U pacientů s CVD je často opomíjeno duplexní ultrasonografické vyšetření (USG) (1)

PROCENTO PACIENTŮ ULTRASONOGRAFICKÝM (USG) VYŠETŘENÍM

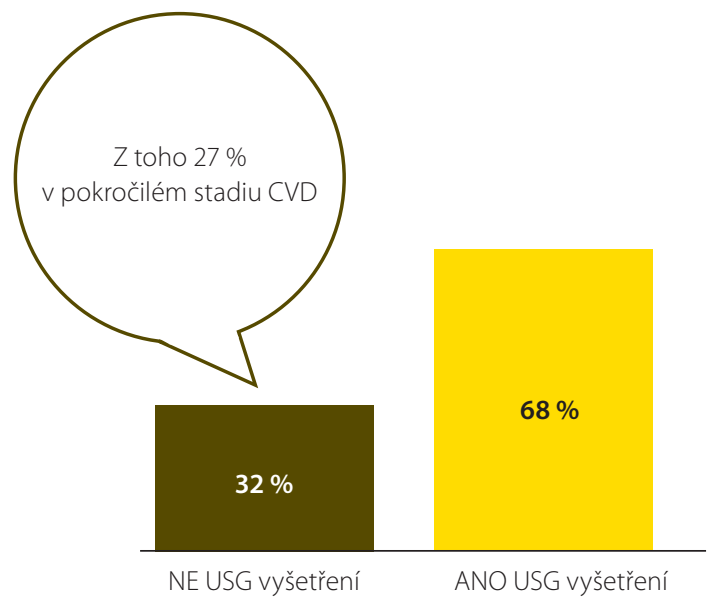

Obr. 3. Kompresivní terapie u českých pacientů s CVD v průzkumu CVD Control (1)

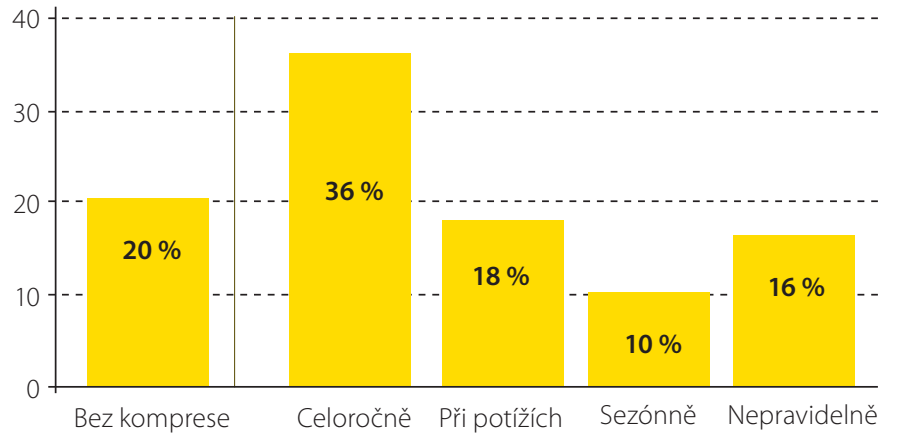

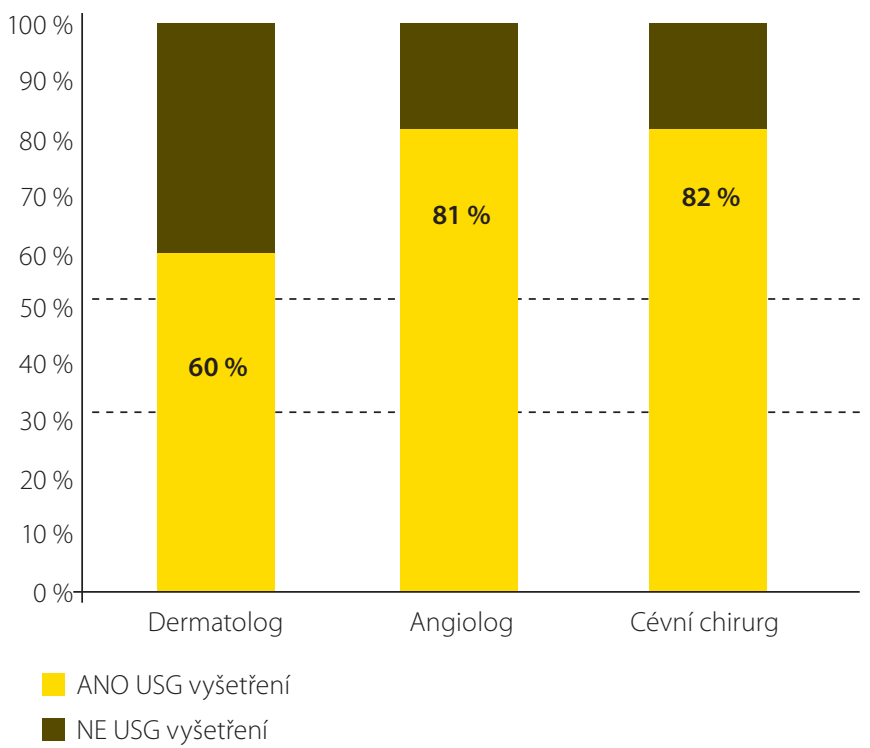

Obr. 4. Patologické změny v žilní stěně prì CVD (12)

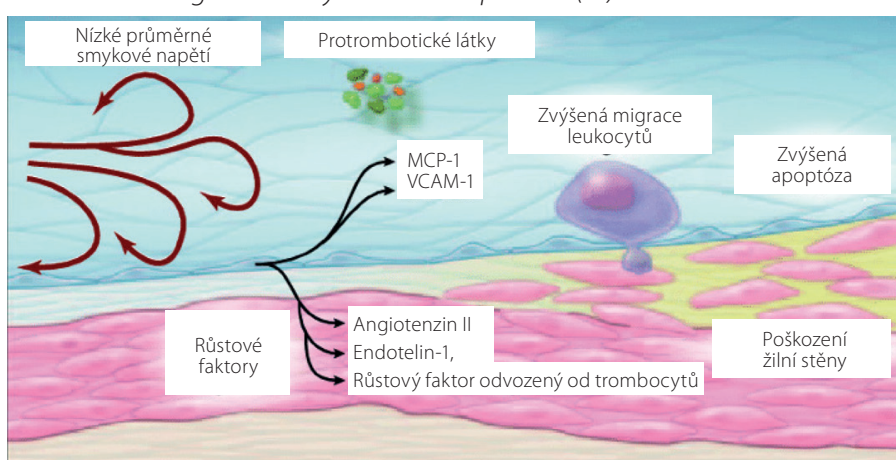




\section{| ZAZNĚLO NA 15. KONFERENCI INTERNÍ MEDICÍNY PRO PRAX |}

PŘEKVAPIVÉ CHYBY V LÉČBĚ ŽILNIIHO ONEMOCNĚNÍ. JAK SE JIM VYHNOUT?

k CVD jsou genetické faktory i faktory vnějšího prostředí, které vedou k hemodynamickým poruchám a zvýšení hydrostatického tlaku v žilách dolních končetin. Dochází ke zpomalení toku krve, dilataci žil a jejich následné dysfunkci v důsledku nedomykání chlopní a žilního refluxu. Zvýšený tlak na žilnî stěnu a vznikající turbulentní proudění pak vede k hypoxii žilní stěny a aktivaci endotelu. Hypoxie aktivuje matrixové metaloproteinázy, které navozují relaxaci hladké svaloviny žilní stěny a degradaci mezibuněčné hmoty. Výsledkem je další dilatace žil. Aktivace endotelu spolu s narušením jeho ochranné vrstvy, kterou tvoří glykokalyx, a imbalancí vazoaktivních látek (NO, prostaglandin 2) vede kadhezi leukocytů a infiltraci žilní stěny těmito imunitními buňkami, které vyplavují prozánětlivé mediátory. Žilní stěna začíná vytvářet také protrombogenní látky. Hypoxie a zánět žilní stěny jsou prríčinou bolesti popisované pacienty a vedou k přestavbě žilní stěny a žilních chlopní. Vznikají teleangiektázie, varixy a prohlubující se dysfunkce žilní stěny podporuje venostázu a reflux. Bludný kruh CVD se uzavírá (10, 11).

\section{LITERATURA}

1. Zimolová P. Aktuální stav manifestace, diagnostiky a léčby chronického žilního onemocnění u pacientů léčených specialisty v ČR - výsledky prưřezového prưzkumu CVD Control. Practicus 2020; 2: 18-21.

2. Yaltirik HP. Therapeutic options to delay the progress of chronic venous disease: the example of micronized purified flavonoid fraction. Medicographia 2018; 40(2): 88-94,

3. Nitecki S, Kantarovsky A, Portnoy I, Bass A. The contemporary treatment of varicose veins (strangle, strip, grill or poison). Isr Med Assoc J. 2006; 8(6): 411-415

4. Robertson L, Lee AJ, Gallagher K, Carmichael SJ, Evans CJ, McKinstry BH, Fraser SC, Allan PL, Weller D, Ruckley CV, Fowkes FG. Risk factors for chronic ulceration in patients with varicose veins: a case control study. J Vasc Surg. 2009; 49(6): 1490-1498.

5. Kostas TI. Chronic venous disease progression and modification of predisposing factors J Vasc Surg 2010; 51: 900-907

6. Nicolaides A, Kakkos S, Baekgaard N, Comerota A, de Maeseneer M, Eklof B, Giannoukas AD, Lugli M, Maleti O, Myers K, Nelzén O, Partsch H, Perrin M. Management of chronic ve-

\section{Závěr}

CVD je celoživotní progredující onemocnění, které může vyústit až do vzniku bércových vředů. Nelze ho proto podceňovat.

Pacienti s príznaky CVD by měli včas vyhledat lékaře. Po stanovení diagnózy pak stojí před úkolem dodržovat režimová opatření, kompresivní léčbu a pravidelné kontroly u lékaře a uživat doporučenou medikaci.

Lékaři musí mít na paměti, že CVD je nutno léčit od počátečních projevů. Měli by využívat mezioborové spolupráce a pacienta vždy komplexně vyšetřit - neopomíjet provedení duplexní ultrasonografie a možnost chirurgického zákroku. V terapii je nutné využít všechny 3 základní složky zahrnující kompresi, režimová opatření a podávání ověřených doporučených venofarmak. Vynechání kterékoliv složky může být pro prognózu pacienta zásadní.

Prripravila MUDr. Zuzana Zafarová

nous disorders of the lower limbs. Guidelines According to Scientific Evidence. Part I. Int Angiol. 2018; 37(3): 181-254

7. Paysant J, Sansilvestri-Morel P, Bouskela E, Verbeuren TJ. Different flavonoids present in the micronized purified flavonoid fraction (Daflon $500 \mathrm{mg}$ ) contribute to its anti-hyperpermeability effect in the hamster cheek pouch microcirculation. Int Angiol. 2008; 27(1): 81-85. Experimentální studie 8. Černohorská J. Víme vše o účincích flavonoidů. Practicus 2018; 6 .

9. Allaert FA. Meta-analysis of the impact of the principal venoactive drugs on malleolar venous edema, Int Angiol; 2012; 31(4): 310-315.

10. Mansilha A, Sousa J. Pathophysiological Mechanisms of Chronic Venous Disease and Implications for Venoactive Drug Therapy. Int J Mol Sci. 2018; 19(6): 1669.

11. Boisseau MR. Mechanisms of onset of chronic venous insufficiency (CVI). Phlebolmyphology. 2003; 41: 161-167.

12. Bergan JJ, Schmid-Schönbein GW, Smith PD, Nicolaides AN, Boisseau MR, Eklof B. Chronic venous disease. N Engl J Med. 2006; 355(5): 488-498. 